\title{
Understanding the tax compliance culture of private sector tax practitioners in South Africa
}

\author{
${ }^{1}$ Oludele Akinloye AKINBOADE*, ${ }^{2}$ Mandisa Putuma MOKWENA \\ ${ }^{1}$ Independent Consultant, Thornbrook Estate, Pretoria North, South Africa \\ 2University of the North West, Vaal Campus, South Africa \\ *economist_oa@yahoo.com
}

\begin{abstract}
The paper presents the findings of a private sector tax practitioners segmentation survey conducted by South Africa Revenue Service to understand their tax compliance culture, appropriateness of SARS services to them and their client service needs. A set of structured questionnaires were administered to seven hundred and three tax practitioners in nine provinces which included open and closed questions. The level of tax compliance by the tax practitioner's organization varies from province to province. Roughly, more than ninety percent of tax practitioners' organizations that filed or submitted their organizations tax returns did so on time. Private sector tax practitioners are good e-filers. On average, assistance provided by SARS officials is considered to be very helpful. They prefer communication via email, internet, letters in the post, television and telephone calls. Most would like a dedicated SARS unit to serve them.
\end{abstract}

Keywords: Culture; Tax compliance, tax practitioners, South Africa

\section{Introduction}

Understanding tax culture: The traditional understandings of a country's "tax culture" is nearly always entirely associated with the definition given by the tax authorities with little consideration being given to the other important segment in the tax system, i.e., the taxpayers. Nerre $(2008,2011)$ suggests that it is not only the tax system and the actual tax practice which form part of a country's "tax culture", but the relationship between the tax authorities and the taxpayers also accounts for its uniqueness. Hofstede (1983) suggests no scientific language to define culture, but refers exclusively to the national culture. It is to be understood as "the collective programming of the mind" (Hofstede 1983). In essence, the tax culture of a particular country emerges - coined by the tradition of taxation on the one hand, and by the interaction of the actors and the cultural values like honesty, justice or also sense of duty on the other hand. Nerre $(2008,2011)$ suggests that tax mentality consists of the two components of tax moral and tax discipline and solely aims at the relationship of the taxpayer to the tax state. Tax mentality includes all attitudes and also all patterns of behavior which the tax-paying citizens hold against the tax and the state (Tretter, 1974). Tax moral is associated with the "willingness-to-pay taxes", a feeling of obligation to the state (according to the benefit principle) or the obligation to the general public or community respectively, while tax discipline reflects the attitudes of the taxpayer to his or her actions. Nerre (2008, 2011) suggests that tax culture contains more than the culture of taxation and tax-paying culture and provides an embedded framework of tax culture, which we have adapted to the South African context in figure 1. It shows the embeddedness of the actors into the South African national culture with its subset of tax culture. Cultural norms and historically developed institutions (such as South African Revenue Service or SARS) both determine the tax code. The South African Revenue Service sets the environment and the constraints, i.e. the rules for the tax game. National players include (among others) taxpayers, politicians, tax officials, expert (e.g. tax practitioners), and academics. Arrows indicate interactions between different groups of players as well as between the members of one and the same group (Nerre, 2008, 2011).

The role of tax practitioners in the tax system: The term "tax practitioner" covers a diverse group of individuals, business structures and professional groups who provide a range of tax services for their clients. Self-employed and in-house accountants, tax advisers and registered tax agents, tax agent franchises and legal practitioners in the tax area are all embraced by the term (Marshall et al., 2006). The role of tax practitioners in the tax system is very important. Roth et al. (1989) suggest that one of the most important influences on compliance behaviour is the community of tax practitioners. Tomasic and Pentony (1991) put their roles into six categories viz: acting (1) as independent advisers of their clients,(2) as unpaid employees of the internal revenue office, (3) as intermediaries between the internal 
revenue office and the taxpayer, (4) as tax advisers, (5) as protectors of their practice and finally as influences on the systems. Importantly, Tomasic and Pentony (1991) conclude that tax practitioners play a major role in increasing the level of taxpayer compliance.

\section{Figure 1: The Embeddedness of South African Tax Culture}

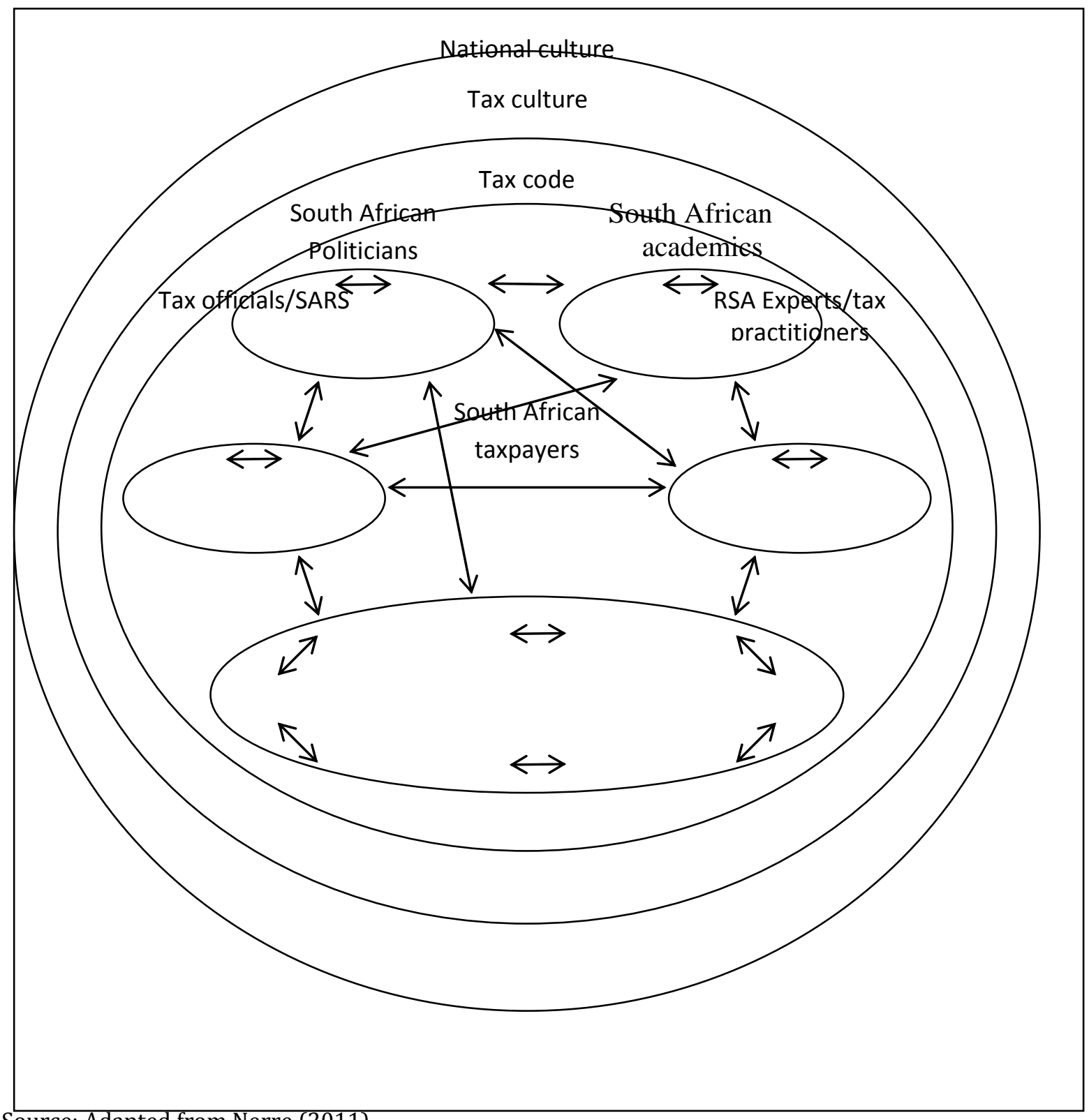

Source: Adapted from Nerre (2011)

Who makes use of tax practitioners: Taxation has become increasingly complex, making it necessary for more taxpayers to take guidance from practitioners. They act as personal advisors to taxpayers. Luscombe (2004) indicates that they should be able to think creatively to help solve business problems with favourable tax ramifications; and which can be utilized effectively in assisting both individuals and businesses to carry out their tax obligations. They reduce compliance costs by reducing legal uncertainties (Beck \& Jung, 1994, Scotchmer 1989) and time or even anxiety costs (Reinganum and Wilde 1991). Klepper, Mazuar and Nagin (1991) find that an expert's participation will discourage noncompliance on legally unambiguous income sources but encourage non-compliance on ambiguous sources. Tax practitioners handle between 1 and 20 taxpayers clients mainly though another significant category handles from 100-500 clients. At 34\%, small businesses are the largest clients of practitioners, followed by salaried individuals at $26 \%$. Thirty eight percent of tax practitioners focus on personal income tax in South Africa (SARS, 2008). 


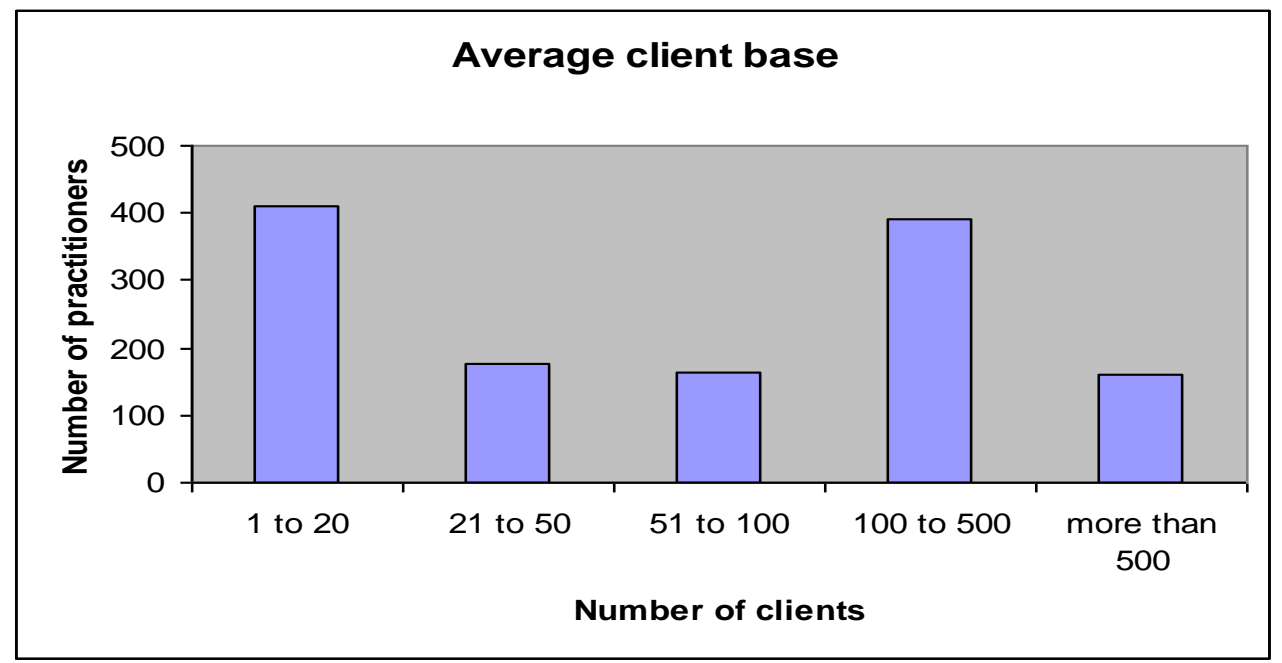

Source: SARS (2008)

Fear and anxiety are very real motivators leading many taxpayers across the entire economic spectrum to rely on tax preparation assistance (O'Connor, 2001). Taxpayers who speak English as a second language (ESL) or who neither speak nor read English constitute a very large category of individuals with unique incentives to rely on formal tax preparation assistance. Prior research shows that the use of paid preparers increases with income, age, self-employment, return complexity, number of dependents claimed, and marginal tax rate and decreases with education and tax knowledge (Slemrod and Sorum 1984; Long and Caudill 1987; Klepper, Mazur, and Nagin 1991; Christian, Gupta, and Lin 1993; Arena, O'Hare, and Stavrianos 2002). As tax returns become more complex due to increases in income, selfemployment and filing complexity, or as time becomes scarcer due to increases in age and dependents claimed, it becomes more cost-effective to hire a preparer. Mckerchar (2005) finds income tax complexities has an enormous impact on tax practitioners in Australia, since the implementation of self assessment system (SAS), tax practitioners are having bigger roles to play in tax compliance. Dubin et al. (1992), show that increases in IRS audit rates, age, state, local and real estate taxes, shift demand for tax preparation services from NTP firms such as H\&R Block to CPAs and attorneys. They also find return complexity increases the demand for CPAs and attorneys at the expense of own-preparation.

Problem Identification Scenario: To date, there have been little published empirical studies on tax practitioners' tax compliance culture in South Africa. Tax compliance is defined is a person's act of filing their tax returns, declaring all taxable income accurately, and disbursing all payable taxes within the stipulated period without having to wait for follow-up actions from the authority (Singh, 2003). An analysis of compliance among South Africa's 35,000 tax advisors shows that, in their personal capacity, they are indebted to SARS to the tune of R260 million, whilst at the same time they have 18,000 outstanding returns (Lee, 2012). Non-compliance by trusts and companies is also a key area of concern for SARS, and it has been determined that tax practitioners could be linked to over 107,600 companies and trusts. Only about 55\% of tax practitioners registered with SARS is registered with any professional body while others have no oversight or accountability (Lee, 2012). Small scale tax practitioners in many developing countries may not have the infrastructure of more established tax practitioners. As taxation becomes more complex, they may be at a disadvantage when it comes to identifying and recording certain taxable line items and hence may risk being non-compliant personally or making their clients noncompliant. Self-employed Chartered Accountants (CAs) or those employed in smaller private and public sector organizations need to be vigilant in the proper identification and recording of taxable items in order to increase compliance with SARS guidelines. Where tax advisors engage in or encourage noncompliance, government needs to address these situations through legislation or monitor closely the audit process. Concerns about limited professionalism in the industry prompted President Zuma, on 21 December 2012, to sign into law new requirements for all SARS tax practitioners which stipulate that they must have bookkeeping and financial accounting skills.

The two key requirements are that tax practitioners must have at least an appropriate, national qualification framework ( NQF) Level 4 qualification (national diploma level qualification); and must be registered with an authorised controlling body, that will administer, regulate, and manage the conduct of 
such tax practitioners. Accredited tax professionals can enjoy greater professional recognition and skills development. As such all tax practitioners were required to update their academic qualifications with SARS before 1 July 2013. An improved understanding of tax practitioner's behaviour (and attitudes to taxation) can help the South Africa Revenue Service to develop stronger and more effective compliance risk treatments for this segment. Tools like audit are an expensive way to attempt to improve compliance, and they have uncertain outcomes. Understanding and influencing behaviour taxpayer may offer an effective but less expensive option. Walsh and White (2000) finds that in the United States, the use of a new tax filing technology has a different appeal for various groups. This is because each group adopts the new technology based on a cost benefit trade-off specific to that cohort". Skillman (1998) suggests that tax practitioners as a group apparently do not see that the conversion to electronic filing offers much to them in terms of return on their investment, considering the cost of software and hardware needed to adopt the e-filing technology. Although many tax practitioners do perceive that electronic filing is an important and improved service; they do not view it as vital in gaining competitive advantage (ACCA, 2002; Kana, 2001). Other studies report that the main reasons for taxpayers' use of electronic filing are related to the speed of getting refunds, speed in the filing process, convenience and the accuracy of the efiling system (Kana, 2001).

Objectives of the study: A private sector tax customer service needs analysis is a process whereby tax compliance needs of private sector organizations are identified and priorities among them established. This is necessary in order to evaluate and to ensure increased tax compliance by these organizations and hence increase internal revenue collection by South Africa Revenue Service. The principal objectives of this study are to:

- Assess tax compliance culture of tax practitioners and their organizations in South Africa and their record keeping practices.

- Define the internal revenue or taxation training needs of private sector tax practitioners in the country;

- Identify their SARS related training and development needs which are to be addressed at a later stage by SARS.

- Determine the necessity for a dedicated SARS Unit focusing specifically on tax practitioners in the private sector.

\section{Culture and Taxation issues as they affect Tax Practitioners}

There are cultural diversities among tax practitioners in South Africa. Despite this, they are all regulated under the same self assessment tax regime which requires fair and honest reporting of their tax liability and to pay their taxes on time (James and Alley, 2000). The study of cultural norms is important as "the efficacy with which a culture equips a people to deal with situations it faces is one of the most important determinants of advantage and disadvantage" (Crocombe, 2008). Chan et al. (2000) suggests that cultural differences have a direct effect on individual taxpayer's compliance behaviour; just as Chau and Leung (2009) consider culture as a powerful environmental factor that influences taxpayer's compliance behaviour. Cultural issues are extremely important in understanding what drives individuals and/or their organisations to compliant behaviours, inspiring some experts to consider how certain aspects of cultural values relate to tax evasion or morale of taxpayers (Richardson, 2006). Social factors such as morality, peer involvement and the threat of social disapproval are all influential in terms of compliance with the law (Gezelius, 2002). These considerations serve to bring about compliance where there is a desire to behave in a way that is socially or morally acceptable to others. Bame-Aldred et al. (2011) study suggests that national culture creates a context that encourages or discourages different rates of tax evasion by firms regardless of other influential individual firm characteristics or other national institutional components. Randall (2004) suggests that influences affecting compliance behaviour can be understood as "normative".

The institutional anomie theory (IAT) (see Messner and Rosenfeld, 2001), identifies specific cultural values that might influence tax evasion. IAT suggests conditions where the willingness, through any means, legitimate or not, to achieve pecuniary benefits like monetary rewards displaces normative behaviour or, in this case, tax compliance (e.g., Cullen, Parboteeah, and Höegl, 2004). Illegal tax evasion can represent an easier and cheaper, albeit riskier, mechanism for a firm to achieve important performance outcomes. 
In broad terms, research streams find that culture envelops attitudes toward tax compliance and evasion. Culture shapes taxpayer attitudes through social learning and environmental influences (Wenzel, 2004). As a result, taxpayer values reflect values generally held by others within the social environment (social norms) (Wenzel, 2005). Culture informs societal members on what is or is not acceptable with regard to values, beliefs, and actions (Schwartz, 1992). Rothengatter (2005a,b) claims that the extent of the influence of cultural norms and values on business conduct and one's payment of taxes may vary from one ethnic (racial) group to another. SME taxpayers are not culturally homogeneous and intra-national variations can often be as significant as cross-national differences (Tung, 2008). Bergman (2002) contends that voluntarily paying taxes is dependent upon social and cultural values. Paying taxes is a shared experience, a shared burden which ties a nations people together and paying taxes is however contingent upon taxpayers having the appropriate social values (Bergman, 2002). The level of tax compliance may be affected by the degree of trust existing in a society (Kimenyi, 2003; Lassen, 2003; Torgler, 2003). A society with cultural fragmentation is likely to experience a low degree of trust among its people and, similarly, a lower level of taxpayers' compliance (Kimenyi, 2003).

Relationship between Tax Practitioners and Tax Administration: Tax practitioners are also the channel of communication between tax authorities, like SARS, and taxpayers, particularly the wealthy ones. They not only provide clients with accounting and tax help, but also help them develop personal budgets, manage assets and investments, plan for retirement, and recognize and reduce their exposure to risks. This role is in response to clients' demands for a single trustworthy individual or firm to meet all of their financial needs. This has enhanced their ability to influence either positively or negatively the attitudes of taxpayers to tax compliance (Killian and Doyle, 2004). Hence, Lederman (2007) suggests that one way in which tax administrators can ease enforcement difficulties is by using third parties as verifiers. Structurally, third parties have the incentive to verify the bona fides of the taxpayers' claim so that they do play an educational role. It is envisaged that the role of tax practitioners can be one of a statutory speed bump' in either slowing or eliminating non-compliance resulting in reduced or little enforcement costs to taxpayers. The relationship between the tax agency and tax advisers could be viewed from an individualist perspective whereby they pursue mutually inconsistent objectives in an adversarial relationship. Some authors opine tax payments are commonly associated with emotions such as hope, despair, anger, outrage, defiance, frustration, disdain, suspicion, and deference (Rawlings and Braithwaite, 2003). While the state is pursuing a goal of revenue maximisation, the ethical obligation of tax advisers is to uphold the law by ensuring that their client pays no more tax than is required by law (Burton and Dabner, 2008). The second view of the relationship flows from Rousseau (1762)'s concept of the 'general will' whereby the individual and the state are not a dichotomy but a unity framed upon a common identity. The tax agency and the tax practitioners could be seen as comprising a partnership which pursues fulfilment of the 'general will' expressed in the community's tax laws. Such a partnership may experience friction, but the parties strive to minimise conflict and seek to achieve negotiated positions and 'practical' outcomes consistent with the 'general will'(Burton \& Dabner, 2008). In this context, Tax agencies need processes that do not just make it easy for citizens to understand their obligations and comply with the rules, but also make it difficult for them not to comply. Above all, systems must be flexible enough to allow prevention and detection strategies and business rules to change regularly, so that agencies are not outmanoeuvred by the constantly evolving tactics of tax evaders (Pretty and Negadi, 2012).

Taxpayer expanded customer service paradigm of Revenue Authorities: Tyler's research (1990, 1997) provides support for the importance of legitimacy and allegiance to authority in compliance decisions. The way people are treated by the authorities affects their evaluations of authorities and their willingness to co-operate (Tyler, Casper and Fisher 1989). A substantial aspect of the work of a tax administration includes activities that cover both compliance and customer service. Many of the functions of tax administration depend to a certain extent on the voluntary compliance of taxpayers. Taxpayer service delivery function plays a crucial role in the administration of the tax legislation in all countries. Providing services that are user-friendly, in the sense of being accessible and understandable for all, helps to maintain and strengthen the taxpayers' willingness to comply voluntarily and thereby contribute to improvements in overall levels of compliance with the laws. Revenue Agencies provide a broad range of services and products related to their different tasks. This ranges from pure dispersion of information, via different types of guidance services, which often include a dialogue between revenue body staff and users, to different types of transactional services. Transaction services are the "core business" of revenue bodies, and the information and interaction services can be seen as services supporting the transaction services. A combination of process change and technology evolution is evident in the most effective tax 
agencies. Their systems and processes have already been modernised to maximise yield by improving compliance (Pretty and Negadi, 2012). Recently, many internal revenue authorities are shifting from the traditional "enforcement" paradigm often used to analyze tax compliance behaviour, in which taxpayers are viewed and treated as potential criminals, and the emphasis is on repression of illegal behaviour through frequent audits and stiff penalties (Allingham and Sandmo, 1972; Yitzhaki, 1974). Table 1 provides examples of revenue agencies service categories.

Table 1: Revenue Agencies Service Categories

\begin{tabular}{|c|c|c|c|}
\hline $\begin{array}{l}\text { Service } \\
\text { category }\end{array}$ & Description & Examples of services & Characteristics \\
\hline Information & $\begin{array}{l}\text { Information } \\
\text { services and } \\
\text { products which are } \\
\text { one way } \\
\text { communication } \\
\text { and do not result in } \\
\text { a change to } \\
\text { account status }\end{array}$ & $\begin{array}{l}\text { (1) Education } \\
\text { (2)Publications (paper } \\
\text { and web) } \\
\text { (3)Campaigns } \\
\text { (4)Mass distribution of } \\
\text { different types of } \\
\text { information } \\
\text { (5)Instructions }\end{array}$ & $\begin{array}{l}\text { (1)Timing volume: partly } \\
\text { predictable } \\
\text { (2)Size volume: flexible, can be } \\
\text { influenced, revenue body initiate } \\
\text { (3)Standardisation/automation: } \\
\text { possible in many cases }\end{array}$ \\
\hline Interaction & $\begin{array}{l}\text { Two-way } \\
\text { communication, } \\
\text { which in itself does } \\
\text { not result in any } \\
\text { change in account } \\
\text { status. }\end{array}$ & $\begin{array}{l}\text { (1)Enquiry } \\
\text { (2)Audit } \\
\text { (3) Guidance } \\
\text { (4)Debt collection }\end{array}$ & $\begin{array}{l}\text { (1) Timing volume: partly } \\
\text { predictable } \\
\text { (2)Size volume: flexible, can be } \\
\text { influenced } \\
\text { (3) standardisation/automation: } \\
\text { difficult }\end{array}$ \\
\hline Transaction & $\begin{array}{l}\text { Activity or services } \\
\text { that result in a } \\
\text { change in account } \\
\text { status or account } \\
\text { information. }\end{array}$ & $\begin{array}{l}\text { (1)Filing of tax returns, } \\
\text { VAT etc } \\
\text { (2)Payment/refund }\end{array}$ & $\begin{array}{l}\text { (1)Timing volume: very } \\
\text { predictable } \\
\text { (2)Size volume: can to a very little } \\
\text { degree be influenced } \\
\text { (3)Standardisation/automation: } \\
\text { great potential }\end{array}$ \\
\hline
\end{tabular}

Source: OECD (2007)

For some time now, revenue bodies have been providing more accessible information services through use of new technology (e.g. by building on-line capability or making information available 24 hours a day, 7 days a week). More recently, many revenue bodies have given taxpayers the functionality of registering for tax system purposes, filing tax returns and paying tax electronically, all at times convenient to them. There have also been developments in the use of telephony services with revenue bodies in many countries establishing large call centre arrangements employing sophisticated telephony technology to facilitate access by phone for taxpayers to the information and other services they require (OECD, 2007). The dynamic way of getting citizens/customers of public services involved in order to enhance their perceptions, expectations and commitment through active participation, has been a common strategy to obtain a legitimate level of quality and satisfaction of public services (OECD, 2001). An expanded "service" paradigm is now being embraced which recognizes the role of enforcement, but also emphasizes the role of tax administration as a facilitator and a provider of services to taxpayer-citizens. This has had significantly positive effects on citizen perception of the tax administration. Customer orientation implies that being actively engaged in the organization-wide generation, dissemination of, and responsiveness to, market intelligence (Kohli and Jaworski 1990). It is usually described as an organizational culture that stresses the customer as the focal point of strategic planning and execution (Jaworski, Kohli, and Sahay 2000; Steinman, Deshpandé, and Farley 2000). Satisfaction is also important to the individual consumer because it reflects a positive outcome from the fulfilment of unmet needs.

The idea of identifying homogenous groups of customers, assessing these segments for size and responsiveness, and then more precisely creating offerings and outreach mixes to satisfy them is not new. Traditional segmentation is most effective when it leads to more precise targeting those results in responsiveness to marketing and outreach programmes. Colemen and Freeman (1997) report that taxpayers would respond more favourably to messages and strategies that explicitly take into account 
cultural, economic and even gender differences. Their views are supported by a similar study carried out by Lin and Carrol (2000). Past studies have shown that women are more responsive to conscience appeal than sanction threat, both of which are designed to improve tax compliance (Jackson and Jaouen, 1989; Hite, 1997). These findings imply that targeting groups that require tax education programmes will increase voluntary tax compliance. The spectrum of services within each category varies from country to country. Many of the revenue bodies, such as the Canadian Revenue Agency (CRA) have placed high priority over the past several years on improving its service delivery over the web. A survey by OECD (2007) finds that several revenue agencies are finding the email channel to be a challenge. It can be more time and cost intensive than initially expected. The survey reports that unstructured email poses the biggest challenge and it can take a long time to respond to such contact. One interviewee reports that users don't come with a question, they come with a problem. Hence, most revenue agencies do offer email as an option, but they do not promote the channel. For the user, email is often seen as an alternative to a telephone call or a letter. Most citizens and businesses see email as a natural part of the communication options and they will often search for an email-address at the website. However, the Netherlands Revenue Agency does not offer email at all, and some other tax administrations have a very limited offer (OECD 2007).

Most revenue agencies have call centre facilities. The next step for some of them is now to transform these into contact centres, where several channels are integrated including e-mail. Overall, with a $90-95 \%$ penetration, the telephone will remain an important channel for revenue bodies' universal access objectives (OECD 2007). Revenue Agencies are aiming for a reduction in the volume of users that are served on face-face basis. One of the main reasons for this is that it is known to be the most expensive channel, and therefore efforts are made to reduce volumes. Revenue Agencies, such as the one in Singapore, are increasing service-orientation by converting from a hard-copy filing system to a paperless imaging system, adopting the extensive use of electronic filing, a one-stop service to answer inquires about any type of tax, the ability for filers to see the entire tax form with any corrections before it is submitted, the use of interest-free installment plans for paying taxes with direct deduction from bank accounts, separate functional areas within the tax administration with little opportunity for corruption, and a changed attitude of officials toward taxpayers. During the last decade, the tax administration service of Singapore has gone from being the lowest rated government agency in public satisfaction to one that ninety percent of the taxpayers found to provide courteous, competent, and convenient services (Alm et al., 2011). In Sweden, the assumption is that many taxpayers want to comply but that they are making mistakes unintentionally and that compliance would increase by focusing on service and information, influencing policy makers and initiating changes in the law to make it easier for users to comply (OECD 2007). Alm et al. (2011) utilize laboratory experiments to test the effectiveness of taxpayer service programmes both in encouraging an individual to file a return ("filing" compliance) and in increasing the individual's subsequent level of reported income ("reporting" compliance). They find that uncertainty reduces both the filing and the reporting compliance of an individual. However, they also find that agency-provided information has a positive and significant impact on the tendency of an individual to file a tax return, and also on reporting for individuals who choose to file a return.

\section{Methodology}

A purposive survey was carried out of the needs of 703 tax practitioners in the nine South African provinces. Gardner and Stewart (1993, p.8) point out that in relation to tax research techniques, questionnaire surveys based on carefully selected statistical samples are deemed appropriate for attitudinal and/or preferential studies. As such, the questionnaire administered included open and closed questions. Open questions allowed respondents to give answers in their own way, while closed questions were chosen in order to produce standardized data that can be analysed. Our research team conducted a structured interview by asking the same questions in the same order in each of the survey areas. The survey sought to determine: (1) registration and filing compliance culture, (2) how SARS assists to boost their tax compliance culture; and (3) client services needs to support their compliance culture in terms of (a) usefulness of SARS general services, (b) their most preferred dedicated SARS services, (c) tax practitioners training needs, and (d) tax practitioners communication needs as between print and non-print media.

Quantification Methods: The survey also gathered information on demographic, and other socioeconomic data including location of business operation by province, level of education, and the possession of specialized tax education. Socio-economic characteristics of tax practitioners covered 
included age and employment which were measured in years, race, gender (male $=1$; female $=0$ ), and education which was measured from basic (0) to postgraduate/possession of professional qualification (5).

Descriptive analysis: Of the 703 questionnaire respondents, 24 are not South African citizens while the other 679 are South African citizens or permanent residents. Most of them are male (57\%) the remainder (43\%) being female. Thirty four percent of them are white, followed by blacks/Africans (29.5\%), coloureds (22.6\%), Indians/Asians (11.8\%) and others (1.52\%). A quarter of them are employed as tax advisers, a quarter as Finance advisors, one-fifth as tax agents with the rest being employed in other professions. They are aged between 20 and 78 years with the average age being 39 years. Forty six percent of them have completed a degree programme, $25 \%$ have obtained a diploma, $18.6 \%$ completed a postgraduate degree or diploma while $1.2 \%$ have other qualifications. About two-third have some form of tax specialization qualification. On average, they have been employed as tax practitioners for nine years. Approximately, three quarters of them are registered tax agents.

\section{Results}

Tax record keeping by tax practitioners

Table 2: Tax practitioner's system use for accounting purposes and tax records

\begin{tabular}{llll}
\hline \multicolumn{1}{c}{ Province } & Manual & $\begin{array}{c}\text { Type of system } \\
\text { Computerized }\end{array}$ & Unsure/don't know \\
\hline Eastern Cape & $28(33 \%)$ & $55(65.5 \%)$ & $1(1.2 \%)$ \\
Free State & $3(7.3 \%)$ & $37(90 \%)$ & $1(2.4 \%)$ \\
Gauteng & $54(37.8 \%)$ & $78(54.5 \%)$ & $11(7.7 \%)$ \\
Kwazulu Natal & $0(0 \%)$ & $80(100 \%)$ & $0(0 \%)$ \\
Limpopo & $0(0 \%)$ & $80(100 \%)$ & $0(0 \%)$ \\
Mpumalanga & $0(0 \%)$ & $81(100 \%)$ & $0(0 \%)$ \\
North west & $0(0 \%)$ & $80(100 \%)$ & $0(0 \%)$ \\
Northern Cape & $33(40 \%)$ & $48(58.9)$ & $1(1.2 \%)$ \\
Western Cape & $0(0 \%)$ & $80(100 \%)$ & $0(0 \%)$ \\
Total & $118(15.7 \%)$ & $619(82.4 \%)$ & $14(1.9 \%)$ \\
\hline
\end{tabular}

In order to determine the fair and the right amount of tax to pay, it is essential for the taxpayer to be transparent in financial transactions by keeping accurate accounting records. Amongst tax practitioners, the culture of using computerized systems for accounting and tax purposes is strongest $(100 \%)$ in Kwazulu Natal, Limpopo, Mpumalanga, North West and the Western Cape provinces. for the other provinces; they use a mix of computerized and manual systems. Overall, in all the provinces combined, $15.7 \%$ use manual system, $82.4 \%$ use a computerized system while $1.9 \%$ are either unsure of or do not know what type of system they use.

Table 3: Tax practitioners' choice of software for record keeping

\begin{tabular}{lll}
\hline $\begin{array}{l}\text { Computerized accounting and tax } \\
\text { keeping }\end{array}$ & record & Tax practitioners (\%) \\
\hline Easy file & $218(23.3 \%)$ \\
Microsoft Excel & $429(45.9 \%)$ \\
Microsoft Access & $196(21 \%)$ \\
Microsoft Word & $72(7.7 \%)$ \\
Other & $19(2 \%)$ \\
\hline
\end{tabular}

The use of excel spread sheet is popular amongst tax practitioners in South Africa. Forty six percent of tax practitioner's use excel. About 23\% use easy file software for their accounting and tax record keeping purposes. Twenty-one percent utilize Microsoft Access and only a small proportion of practitioners use Microsoft Word. A small proportion, 2\% use other kinds of software.

\section{Tax Practitioners' filing of tax returns}

Tax compliance by tax practitioner's organizations: The level of tax compliance by tax practitioner's organization varies from province to province. All of the tax practitioners in the Free State have been 
assisted by their organizations in either filing or submitting their tax returns. This is closely followed by Gauteng province where the tax practitioner's organization has filed or submitted their tax returns $93 \%$ of the time. 80.5\% of tax practitioner's organizations in Mpumalanga have filed out or submitted their tax returns. Results are lowest in the Northern and Eastern Cape provinces where $45 \%$ and $48 \%$ of tax practitioners have been helped to file or submit tax returns by their organizations.

Table 4: Organization filled or submitted tax returns?

\begin{tabular}{lll}
\hline Province & Yes & No \\
\hline Eastern Cape & $39(48.7 \%)$ & $41(50.6 \%)$ \\
Free State & $41(100 \%)$ & 0 \\
Gauteng & $93(91.2 \%)$ & $9(8.8 \%)$ \\
Kwazulu Natal & $56(70 \%)$ & $24(30 \%)$ \\
Limpopo & $56(70 \%)$ & $24(24 \%)$ \\
Mpumalanga & $66(80.5 \%)$ & $16(19.5 \%)$ \\
North west & $56(70 \%)$ & $24(30 \%)$ \\
Northern Cape & $36(45 \%)$ & $44(55 \%)$ \\
Western Cape & $52(65 \%)$ & $28(35 \%)$ \\
Total & $495(70 \%)$ & $208(30 \%)$ \\
\hline
\end{tabular}

Tax practitioners filing compliance culture: Almost half of tax practitioners surveyed complete tax returns by themselves. About $30 \%$ make use of the services of tax advisors when completing the forms and almost one fifth use the services of a SARS official. A relatively small proportion $(2.5 \%)$ of them employ the services of friends or family members to file returns while $2.1 \%$ use others.

\section{How Tax practitioner's organization submit tax returns}

Table 5: Who submits tax returns?

\begin{tabular}{|c|c|c|c|c|}
\hline $\begin{array}{l}\text { Submission of } \\
\text { returns }\end{array}$ & $\operatorname{tax}$ & Finance department & Tax consultant & Others \\
\hline Eastern Cape & & $36(46.1 \%)$ & $10(12.8 \%)$ & $31(41 \%)$ \\
\hline Free State & & $20(22.7 \%)$ & $16(18.2 \%)$ & $52(59.1 \%)$ \\
\hline Gauteng & & $75(51.4 \%)$ & $66(45.2 \%)$ & $5(3.4 \%)$ \\
\hline Kwazulu Natal & & $37(46 . \%)$ & $35(44 \%)$ & $8(10 \%)$ \\
\hline Limpopo & & $41(34 \%)$ & $80(66 \%)$ & 0 \\
\hline Mpumalanga & & $56(69.1 \%)$ & $7(8.6 \%)$ & $18(22.2 \%)$ \\
\hline North West & & $41(51.3 \%)$ & $39(48.7 \%)$ & $0(0 \%)$ \\
\hline Northern Cape & & $34(44.7 \%)$ & $18(23.1 \%)$ & $26(33.3 \%)$ \\
\hline Western Cape & & $37(46.3 \%)$ & $43(53.7 \%)$ & $0(0 \%)$ \\
\hline
\end{tabular}

In the majority of cases in Eastern Cape, tax returns are submitted almost equally by the organization's finance department (46.1\%) and other means (41\%). In the Free state, more than half of the tax returns are submitted through other means while in Gauteng, just over half $(51.4 \%)$ of tax returns are submitted via tax practitioners finance department. The submissions of tax returns is evenly divided between the finance department (46\%) and by tax consultants (44\%). Two thirds of tax practitioners returns are submitted by tax consultants in Limpopo. In Mpumalanga, tax returns are submitted mostly by the finance department (69.1\%). In the North West province, tax returns are submitted mainly through the finance department (51.3\%) and tax consultants (48.7\%). In the Northern Cape, submission of tax returns is more evenly spread, $44.7 \%$ by the finance department, $33.3 \%$ through other means and $23.1 \%$ by tax consultants. In the Western Cape, returns are submitted mostly through tax consultants (53.7\%) and by the finance department (46.3\%).

Tax practitioners' organization filing compliance: Roughly, more than $90 \%$ of tax practitioners' organizations that filed or submitted their organizations tax returns did so on time.

Tax practitioner's organizations which submitted returns on behalf of taxpayer clients to ensure taxpayer filing compliance: Seventy one percent of tax practitioners agree that their organization has completed or submitted their tax returns on time. Some $27.2 \%$ have not done so while the remaining tax practitioners are unsure if the tax returns are submitted on time or not. 
Methods used in filing tax returns: It is crucial to understand the nature of tax practitioner's tax returns filing culture. An e-filing system encompasses the use of the internet technology, the worldwide web and tax preparation software for a wide range of tax administration and compliance purposes (FTA, 2001). The chief advantage of an e-filing system is that it integrates tax preparation, tax filing and tax payment. With the e-filing system, taxpayers and tax practitioners can file income tax returns electronically via the enabling technologies, rather than through mail or physically visiting the tax office. The tax authorities in the US, UK and Australia are counting on tax practitioners to promote the e-filing system (Kahan, 1999; NAO, 2002). Thus, in a similar vein, SARS is also counting on public sector tax practitioners to promote the e-filing system. As such, there is a practical need for the e-filing system to be acceptable to the tax practitioners. South African private sector tax practitioners are good e-filers. Roughly, over four-fifth used electronic applications to file or submit client's tax returns. Others either use manual submission or unsure of the process. Results from Malaysia also suggest that tax practitioners have positive attitudes towards using the e-filing system and perceive that an e-filing system was useful and easy to use. Research surveys indicate a strong usage intention of the e-filing system, with mean score of 4.04 on a 5point scale, significant at 1\% level (Ming-Ling, et al., 2005). These results may suggest tax practitioners appreciate the practical usability and ease of use of the tax technology in enhancing their job performance. They may therefore accept a technology that is easy to use and can enhance their job performance in providing tax service to clients in the future.

Tax practitioner's reconciliation of employee records with SARS: Fifty-five percent of tax practitioners have been involved in reconciling their clients' records with SARS. A substantial proportion $(42 \%)$ have not. For those involved in reconciliation of clients' records, $67 \%$ undertake monthly reconciliation with SARS.

Table 6: Reasons for not submitting tax returns

\begin{tabular}{ll}
\hline Lack of time to complete and submit & $25(28.7 \%)$ \\
Tax forms are too complicated & $18(21 \%)$ \\
Don't want to divulge income to SARS & $31(36 \%)$ \\
$\begin{array}{l}\text { Have no interest in submitting tax return } \\
\text { Income is not within bracket that warrants tax } \\
\text { payment }\end{array}$ & $2(2.3 \%)$ \\
Other & $8(3.4 \%)$ \\
\hline
\end{tabular}

Personal tax non-compliance by tax practitioners: Not submitting tax returns is mainly due to people not wanting their incomes disclosed to SARS (36\%). Otherwise, they have no time to complete and submit the forms (28.7\%). For about one-fifth of respondents, tax return forms are too complicated to understand, making completing them difficult. Some feel that their incomes do not fall within the brackets for which they are required to pay tax. Others simply have no interest in submitting their tax return or have some other reasons for not submitting.

Table 7: The degree of helpfulness of SARS and others in assisting to complete tax returns

\begin{tabular}{lll}
\hline Degree of helpfulness & SARS Officials ( average score) & Others \\
\hline Very helpful and helpful & 0.76 & 0.16 \\
Impartial & 0.11 & 0.04 \\
Not very helpful or unhelpful & 0.06 & 0.09 \\
Unsure or NA & 0.05 & 0.71 \\
\hline
\end{tabular}

SARS helpfulness in completing tax returns: Some tax practitioners embrace the culture of using various professionals to complete tax returns. On average, assistance provided by SARS officials is considered to be very helpful (76\%). Assistance received from other kinds of professionals when completing tax returns is considered to be mostly not helpful.

Use of SARS website by tax practitioners: Information search is also important for compliance. Legris, Ingham \& Collerette (2003) indicate that self reported usage intention of technology should serve as a relative indicator of strong intention. When asked to indicate how often they visit SARS website, about thirty five percent visit the site once a month and at the other extreme one-fifth do so only during the filing season. 
Table 8: Frequency of visit to the SARS website

\begin{tabular}{ll}
\hline Frequency of visit & Tax practitioners \\
\hline Once a month & $266(35 \%)$ \\
$2-4$ times a month & $131(17.4 \%)$ \\
$5-8$ times a month & $68(9 \%)$ \\
$9-15$ times a month & $58(7.7 \%)$ \\
Daily & $48(6.4 \%)$ \\
Only during filling season & $155(21 \%)$ \\
Other & $27(3.6 \%)$ \\
\hline
\end{tabular}

Table 9: type of information being searched for on the SARS website

\begin{tabular}{ll}
\hline Type of information & Response \\
\hline Tax & $364(51.8 \%)$ \\
Policy & $265(38 \%)$ \\
Electronic services & $280(40 \%)$ \\
Up to the minute information & $182(26 \%)$ \\
Forms & $233(33 \%)$ \\
Publications & $207(30 \%)$ \\
Frequently asked questions & $266(38 \%)$ \\
Other & $22(3.1 \%)$ \\
\hline
\end{tabular}

Information search on SARS website: Understanding the requirements imposed by the frequent changes of tax laws as well as the language of the tax law requires tax practitioners to be kept regularly informed of developments. In this context, searching information on SARS website is a useful way of keeping taxpayers update with tax legislations. Of those who visit SARS website, majority of them are interested mostly in information regarding tax, electronic services, frequently asked questions, policy information and forms.

Client services support needs of tax practitioners: OECD (2012) suggests that tax administration should determine what target taxpayers want by simply asking them via interviews, surveys, focus groups, etc. The findings should be used in implementing new services and procedures.

Communication needs of tax practitioners: There is a practical need for SARS to encourage voluntary compliance through improved taxpayer knowledge of compliance matters. This could be done through marketing, education and training programs, by effectively disseminating and share information to improve compliance via its websites, mass media and professional accounting bodies. Hence, the survey analyzed tax practitioners' communication needs from SARS. Tax practitioners prefer communication via email, internet, letters in the post, television and telephone calls. The least preferred communication media are imbizo, SMS and radio.

Table 10: Tax Practitioners preferred mode of communication with SARS (from 0 (not preferred) 1 (most preferred)

\begin{tabular}{|c|c|c|}
\hline 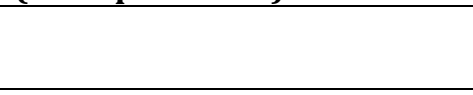 & $\begin{array}{l}\text { Most preferred and preferred. } \\
\text { (average score) }\end{array}$ & Rank \\
\hline $\begin{array}{ll}\text { Community } & \text { theatre } \\
\text { production } & \end{array}$ & 0.23 & 42 \\
\hline Email & 0.72 & 1 \\
\hline Imbizo & 0.28 & 10 \\
\hline Internet & 0.71 & 2 \\
\hline Post & 0.67 & 3 \\
\hline Newspapers & 0.54 & 6 \\
\hline Other & 0.11 & 11 \\
\hline pamphlets & 0.38 & 9 \\
\hline Radio & 0.51 & 7 \\
\hline Sms & 0.43 & 8 \\
\hline Telephone call & 0.55 & 5 \\
\hline Television & 0.58 & 4 \\
\hline
\end{tabular}


Preferred frequency of communication with SARS: Most of the respondents prefer receiving communication from SARS monthly.

SARS Brochure information: Two-thirds (68\%) of tax practitioners would prefer to receive SARS information brochures at their work place. The most preferred type of brochure is filing (36\%), declaration (30\%) and registration brochures (31\%).

Table 11: preferred language of communication

\begin{tabular}{ll}
\hline Language of communication & Tax Practitioners \\
\hline Afrikaans & 70 \\
English & 614 \\
Indian & 12 \\
Xhosa & 18 \\
Zulu & 6 \\
Sepedi & 4 \\
Sotho & 3 \\
Other & 9 \\
Other European language & 4 \\
\hline
\end{tabular}

Preferred means of communication with tax practitioners: The overwhelming preference is for SARS to communicate in English.

Conclusion about customer service communication needs: Tax practitioners clearly identify communication by email and internet as the most important communication need. Filing, declaration and registration brochures are the preferred brochures. And the overwhelming majority of tax practitioners would prefer English as the mode of communication. This kind of needs analysis will help SARS to redirect its limited resources to provide the most effective means of communication to optimize taxpayer compliance.

Tax practitioners most preferred dedicated SARS services: An analysis of responses by tax practitioners reveals varying demand for dedicated SARS information services which include the following five services classified as the dedicated SARS services. These are: SARS web information service, SARS Kiosk, Dedicated SARS desk; Dedicated SARS call centre and Dedicated Teller in SARS Branch Office. The tax practitioners have been asked to rank a number of services provided by SARS.

Table 12: The preferred SARS dedicated service

\begin{tabular}{ll}
\hline SARS mobile service office & $129(14.9 \%)$ \\
SARS kiosks & $168(19.4 \%)$ \\
Dedicated SARS desk & $174(20 \%)$ \\
Dedicated SARS call centre & $180(20.8 \%)$ \\
Dedicated SARS office for tax practitioners & $155(17.9 \%)$ \\
Dedicated teller with SARS office branch & $58(6.7 \%)$ \\
\hline
\end{tabular}

Tax Practitioners preference for dedicated SARS service: Close to two-third $(64.2 \%)$ of tax practitioners would like a dedicated SARS unit to serve them. The most preferred services are the SARS call centre, SARS desk, SARS kiosk and SARS office for tax practitioners.

Table 13: frequency of potential use of the above services

\begin{tabular}{ll}
\hline Daily & $71(12.5 \%)$ \\
Weekly & $155(27.4 \%)$ \\
Monthly & $151(26.7 \%)$ \\
Quarterly & $139(24.4 \%)$ \\
Bi annually & $30(5.3 \%)$ \\
annually & $20(3.5 \%)$ \\
\hline
\end{tabular}

Of the respondents who would like a dedicated SARS unit to serve tax practitioners, a quarter each would make use of the services on a weekly, monthly or quarterly basis. 
Tax Practitioners future training needs to be provided by SARS: SARS needs to provide free hands-on training courses to educate tax practitioners. South African Tax practitioners prefer to be trained by SARS in the knowledge of organizational skills, taxpayer rights and privileges, South African tax laws, computer skills for accounting, and knowledge of tax codes. The least preferred training is in the handling of grievances.

Table 14: Preferred training needs of tax practitioners

\begin{tabular}{ll}
\hline Knowledge of organizational skills & $171(24 \%)$ \\
Tax payer rights and privileges & $155(22 \%)$ \\
Knowledge of tax codes & $149(21 \%)$ \\
South African tax laws & $155(22 \%)$ \\
Tax registration, filling, declaration and payments & $106(15 \%)$ \\
Basic book keeping skills & $95(13.5 \%)$ \\
Computer skills for accounting & $151(21.5 \%)$ \\
Handling of grievances & $45(6.5 \%)$ \\
other & $18(2.7 \%)$ \\
\hline
\end{tabular}

Frequency of training to be provided by SARS as required by tax practitioners: Majority of tax practitioners want SARS to provide such training on quarterly basis, while a very close $23.2 \%$ would like the training to be organized on monthly basis.

\section{Summary and conclusion}

This study reports the results of a survey of tax compliance culture of tax practitioners in South Africa and their and customer service needs to boost tax compliance. The needs analysis is the process by which the taxpayer segment compliance levels are evaluated and their compliance needs are identified. Information about the needs of tax practitioners were identified using a structured survey questionnaire. The South African tax practitioner is highly skilled and has some form of professional qualification. Close to three quarters (73.4\%) of those surveyed were registered tax agents. The culture of using computerized system of accounting is strong. The use of excel spread sheet is also popular among them. They file tax returns on behalf of their clients and they do so electronically.

Future Policy Direction for South Africa Revenue Service: Tax practitioner needs analysis will be of tremendous benefit in helping SARS to redirect its limited resources to provide the most effective services to this taxpayer segment. Tax practitioners prefer communication via email, internet, letters in the post, television and telephone calls. Tax practitioners prefer to be trained by SARS in the knowledge of organizational skills, taxpayer rights and privileges, South African tax laws, computer skills for accounting, and knowledge of tax codes. The least preferred training is in the handling of grievances. SARS should therefore focus future tax practitioners training needs on these identified areas. SARS should dedicate call centre, SARS desk, SARS kiosk and SARS office services for tax practitioners in the future and communicate with them by email and via the internet.

\section{References}

ACCA. (2002). ACCA member's survey: Self-assessment March 2002. The Association of Chartered Certified Accountants.

Allingham, M. G. \& Sandmo, A. (1972). Income tax evasion: A theoretical analysis. Journal of Public Economics, 1(3-4), 323-38.

Alm, J., Todd, C., Jones, M. \& McKee, M. (2011). Taxpayer Information Assistance Services and Tax Compliance Behavior. Tulane University, Economics Working Paper Series, Working Paper 1101, April

Arena, P., O'Hare, J. F. \& Stavrianos, M. P. (2002). Measuring Taxpayer Compliance Burden: A Microsimulation Approach. National Tax Association - Proceedings, 333-341.

Bame-Aldred, C. W., Cullen, J. B., Martin, K. D. \& Praveen, P. K. (2011). National culture and firm-level tax evasion. Journal of Business Research, JBR-07344; No of Pages 7, Article in Press.

Beck, P. J. D. \& Jung, W. (1994). Tax Advise and Reporting Under Uncertainty: Theory and An Experimental Evidence. Working Paper, University of Illinois.

Bergman, M. S. (2002). Who Pays for Social Policy? A Study on Taxes and Trust. The Journal of Social Policy, 31(2), $289-305$. 
Burton, M. \& Justin, D. (2008). The partnership models of the relationship between tax administrator tax practitioners: drivers, challenges and prospects. Journal of Australia Taxation, 11(2), 108-137

Chan, C. W., Troutman, C. S. \& O'Bryan, D. (2000). An expanded model of taxpayer compliance: Empirical evidence from USA and Hong Kong. Journal of International Accounting, Auditing and Taxation, 9(2), 83-103.

Chau, G. \& Leung, P. (2009). A critical review of Fischer's tax compliance model: A research synthesis. Journal of Accounting and Taxation, 1(2), 34-40.

Christian, C. W., Sanjay, G. \& Suming, L. (1993). Determinants of Tax Preparer Usage: Evidence from Panel Data. National Tax Journal, XLVI (4), 487-503.

Colemen, C. \& Freeman, L. (1997). Cultural foundations of taxpayer attitudes to voluntary compliance. Australian Tax Forum, 13(3), 311-336.

Crocombe, R. (2008). The South Pacific (7th ed.). Suva: IPS Publications: University of the South Pacific.

Cullen, J. B., Parboteeah, K. P. \& Höegl, M. (2001). Cross-national differences in managers' willingness to justify ethically suspect behaviors: a test of institutional anomie theory. Academic Management Journal, 47, 411-21.

Department of Public Service and Administration. (2003). The Machinery of Government: Structure and Functions of Government, Available at: http://www.dpsa.gov.za/documents/lkm/mog.pdf, accessed on 20 Feb 2009

Dubin, J. A., Graetz, M. J., Udell, M. A. \& Louis, L. W. (1992). The Demand for Tax Return Preparation Services. The Review of Economics and Statistics, 74, 75-82.

Federation of Tax Administrators. (2001). State electronic tax administration. Federation of Tax Administrators, Available at: http://www.taxadmin.org/fta/edi/default.ssi, accessed on 21-032009

Gardner, R. L. \& Steward, D. N. (1993). Tax Research Techniques (Fourth ed.). Newsbury Park, London: Institute of Certified Public Accountant.

Gezelius, S. S. (2002). Do Norms Count? State Regulation and Compliance in a Norwegian Fishing Community. Acta Sociologica, 45(4), 305-314

Hite, P. A. (1997). An investigation of moral suasion and vertical equity arguments on intended taxpayer compliance. Law and Policy, 19(1), 1-22.

Hofstede, G. (1983). The Cultural Relativity of Organizational Practices and Theories. Journal of International Business Studies, 14(2), 75-89

Jackson, B. R. \& Jaouen, P. R. (1989). Influencing taxpayer compliance through sanction threat or appeals to conscience. Advances in Taxation, 2, 31-147.

James, S. \& Alley, C. (2000). Tax compliance, self-assessment and tax administration. Journal of Finance and Management in Public Services, 2(2), 27-42.

Jaworski, B., Kohli, A. \& Sahay, A. (2000). Market Driven versus Driving Markets. Journal of the Academy of Marketing Science, 28(1), 45-54.

Kahan, S. (1999). Promoting e-filing. The Practical Accountant, 32(10), 69-73.

Kana, L. (2001). Taxing time for e-government. The OECD Observer, 224, 50-51.

Killian, S. \& Doyle, E. (2004). Tax Aggression among Tax Professionals: The Case of South Africa. Journal of Accounting, Ethics and Public Policy, 4(3), 159-189

Kimenyi, M. S. (2003). Ethnicity, governance and provision of public goods. Working paper 2003-49R, University of Connecticut.

Klepper, S., Mazur, M. \& Nagin, D. (1991). Expert Intermediaries and Legal Compliance: The Case of Tax Preparer. The Journal of Law and Economics, XXXIV, 205-229.

Kohli, A. K. \& Jaworski, B. J. (1990). Market Orientation: The Construct, Research Propositions, and Managerial Implications. Journal of Marketing, 54, 1-18.

Lassen, D. D. (2003). Ethnic division and the size of the informal sector. Working paper, Institute of Economics, University of Copenhagen.

Lederman, L. (2007). Statutory Speed Bumps: The Roles Third Parties Play in Tax Compliance. Stanford Law Review, 60(3), 695-743.

Lee, R. (2012). SARS Focuses On Tax Practitioners' Compliance. Tax-News.com, London, Thursday, July 19 , available

at

http://www.lowtax.net/asp/story/front/SARS_Focuses_On_Tax_Practitioners_Compliance__5 6409.html, accessed on 12-11-2012

Legris, P., Ingham, J. \& Collerette, P. (2003). Why do people use information technology? A critical review of the technology acceptance model. Information and Management, 40, 191-204.

Lin, M. T. \& Carrol, C. (2000). The impact of tax knowledge on the perception of tax fairness and attitudes towards compliance. Asian Review of Accounting, 8(1), 44-58. 
Long, J. E. \& Steven B. C. (1987). The Usage and Benefits of Paid Tax Return Preparation. National Tax Journal, 40(1), 35-46.

Luscombe, M. (2004). Can Tax Professionals Be Creative without Being Abusive? Taxes, 82(9), 3-4.

Marshall, R., Smith, M. \& Armstrong, R. (2006). The Impact of Audit Risk, Materiality and Severity on Ethical Decision Making; An Analysis of the perceptions of Tax Agents in Australia. Managerial Auditing Journal, 21(5), 499.

McKerchar, M. (2005). The impact of income tax complexity on practitioners in Australia. Australian Tax Forum, 20(4), $529-554$

Messner, S. F. \& Rosenfeld, R. (2001). Crime and the American dream. Belmont, CA: Wadsworth;

Ming-Ling, L., Obid, S. N. S. \& Meera, A. K. (2005). Tax practitioners and the electronic filing system: an empirical analysis. Academy of Accounting and Financial Studies Journal, 9(1).

National Audit Office (UK). (2002). E-Revenue, London: National Audit office.

Nerré, B. (2011). Tax Culture as a Basic Concept for Tax Policy Advice, German Technical Cooperation (GTZ), Germany, pp1-18, available at https://editorialexpress.com/cgibin/conference/download.cgi?.., accessed on28-03-2013.

Nerré, B. (2008). Tax Culture: A Basic Concept for Tax Politics. Economic Analysis and Policy, 38(1), 153168

O'Connor, M. (2001). Tax Preparation Services for lower income filers: a glass half full, or half empty. Tax Notes, Tax Analyst Special Report, January, 231-250

Organisation for Economic Cooperation and Development. (2012). Working Smarter in Revenue Administration - Using Demand Management Strategies to meet Service Delivery Goals, Forum on Tax Administration, available at http://www.oecd.org/site/ctpfta/49428187.pdf., accessed on 13-01-2014

Organisation for Economic Cooperation and Development. (2007). Improving Taxpayer Service Delivery: Channel Strategy Development. Guidance Note, Forum on Tax Administration, Taxpayer Services Sub-group, May.

Organisation for Economic Cooperation and Development. (2001). Engaging Citizens in Policy-making: information, consultation and public participation. PUMA Policy Brief, 10, 6.

Pretty, I. \& Negadi, A. (2012). Tackling 'disturbing' tax evasion and avoidance. Public Service Europe, available at http://www.publicserviceeurope.com/article/1969/tackling-the-disturbingproblems-of-tax-evasion-and-avoidance, accessed on 4-11-2012

Randall, J. K. (2004). Improving Compliance in U.S. Federal Fisheries: An Enforcement Agency Perspective. Ocean Development and International Law, 35(4), 287-317

Rawlings, G. \& Braithwaite, V. (2003). Voices for change: Australian perspectives on tax administration. Australian Journal of Social Issues, 38(3), 263-268.

Reinganum, J. F. \& Wilde, L. L. (1991). Equilibrium Enforcement and Compliance in the Presence of Tax Practitioners. Journal of Law Economics and Organization, 7, 163-181.

Richardson, G. (2006). Determinants of tax evasion: a cross-country investigation. Journal of International Accounting, Auditing and Taxation, 15, 150-69.

Roth, J. A., Scholz, J. T. \& Witte, A. D. (1989). Taxpayer Compliance, Volume 1: An Agenda for Research. Philadelphia, PA: University of Pennsylvania Press.

Rothengatter, M. (2005a). Social networks and tax (non-) compliance in a multicultural nation: Emerging themes from a focus group study among ethnic minorities in Australia. International Journal of Entrepreneurial Behaviour and Research, 11(4), 280-314.

Rothengatter, M. (2005b). Sticks, carrots or sermons? - Improving voluntary tax compliance among migrant small-business entrepreneurs of a multi-cultural nation, Working paper 82 Centre for Tax System Integrity, Research School of Social Sciences, Australian National University. Canberra.

Rousseau, J. J. (1762). The Social Contract, or Principles of Political Right, bk 1, chapter 6. Translated 1782 by G. D. H. Cole, public domain

Schwartz, S. H. (1992). Universals in the content and structure of values, In: Zanna M, editor. Advances in experimental social psychology, 25. New York: Academic Press. p. 1-65.

Scotchmer, S. (1989). The Effect of Tax Advisors on Tax Compliance, in: Roth, J.A \& Scholz, J.T. (eds.), Taxpayer Compliance: Social Science Perspective, University of Pennsylvania Press, 2, pp.182199.

Singh, V. (2003). Malaysian Tax Administration. 6th ed. Kuala Lumpur: Longman.

Skillman, B. (1998). Fired up at the IRS. Accounting Technology, 14 (January): 12-20.

Slemrod, J. \& Sorum, N. (1984). The Compliance Cost of the U.S. Individual Income Tax System. National Tax Journal, 37(4), 461-474. 
South Africa Revenue Service. (2008). Overview of Tax Practitioners in South Africa. Pretoria.

Steinman, C., Deshpandé, R. \& Farley, J. U. (2000). Beyond Market Orientation: When Customers and Suppliers Disagree. Journal of the Academy of Marketing Science, 28(1), 109-19.

Torgler, B. (2003). Tax morale: Theory and analysis of tax compliance, unpublished doctoral dissertation, University of Zurich, Switzerland.

Tomasic, R. \& Pentony, B. (1991). Taxation Law Compliance and the Role of Professional Tax Advisers. Australian and New Zealand Journal of Criminology, 24, 241-257.

Tretter, B. (1974). Die Steuermentalität - Ein internationaler Vergleich, Berlin, Duncker \& Humblot, p. 39

Tung, R. (2008). The cross-cultural research imperative: the need to balance cross-national and intranational diversity. Journal of International Business Studies, 39, 41-46.

Tyler, T. R. (1990). Justice, Self-Interest, and the Legitimacy of Legal and Political Authority, in: Mansbridge, J.J. (ed.), Beyond Self-Interest. Chicago: University of Chicago Press, pp.171-179.

Tyler, T. R. (1997). Procedural Fairness and Compliance with the Law. Swiss Journal of Economics and Statistics, 133, 219-240.

Tyler, T. R., Casper, J. D. \& Fisher, B. (1989). Maintaining Allegiance toward Political Authorities: The Role of Prior Attitudes and the Use of Fair Procedures. American Journal of Political Science, 33, 629652.

Walsh, S. T. \& White, C. G. (2000). Congress's goal of increasing electronic Filing: An assessment based on the technology-adoption literature. Accounting Horizon, 14(4), 403-425.

Wenzel, M. (2005). Motivation or rationalisation? Causal relations between ethics, norms and tax compliance. Journal of Economic Psychology, 26, 491-508.

Wenzel, M. (2004). An analysis of norm processes in tax compliance. Journal of Economic Psychology, 25, $213-28$.

Westat Inc. (1980). Individual Income Tax Compliance Factors Study. Qualitative Research. United States Internal Revenue Service, February.

Yitzhaki, S. (1974). A Note on Income Tax Evasion: A Theoretical Analysis. Journal of Public Economics, 3, 201-202. 